\title{
Penerapan Model Pembelajaran Kooperatif Tipe Word Square untuk Meningkatkan Hasil Belajar
}

\author{
Akhmad Syahid ${ }^{\mathrm{a}, 1}$, Syamsul Bachri ${ }^{\mathrm{a}, 2}$

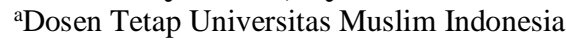 \\ 1akhmad.syahid@umi.ac.id; ${ }^{2}$ syamsul.bakhri@umi.ac.id
}

\begin{abstract}
Abstrak
Salah satu model pembelajaran yang memungkinkan peserta didik untuk berinteraksi satu sama lain adalah model pembelajaran kooperatif tipe word square. Model pembelajaran tipe ini adalah peserta didik bekerja sama dalam kelompok kecil dan saling membantu dalam belajar dapat memotivasi peserta didik, memanfaatkan seluruh energi sosial peserta didik, saling mengambil tanggung jawab. Model pembelajaran tipe word square membantu peserta didik belajar menemukan topik-topik materi pelajaran sesuai dengan konten dan keadaan peserta didik dalam lingkungan mereka. Menemukan kata-kata yang sesuai dengan permasalahan yang diberikan selama pembelajaran.
\end{abstract}

Kata kunci: pembelajaran; kerjasama; hasil belajar

\section{Pendahuluan}

\subsection{Latar Belakang Masalah}

Pendidikan adalah usaha sadar dan terencana untuk mewujudkan suasana belajar dan proses pembelajaran agar peserta didik secara aktif mengembangkan potensi dirinya untuk memiliki kekuatan spiritual keagamaan, pengendalian diri, kepribadian, kecerdasan, akhlak mulia, serta keterampilan yang diperlukan dirinya, masyarakat, bangsa dan negara" 1

Proses pembelajaran yang sesuai dengan undang-undang tersebut merupakan proses pembelajaran yang mampu menciptakan sistem lingkungan yang memungkinkan terjadinya belajar bagi siswa. Sistem lingkungan ini terdiri dari komponen-komponen yang saling mempengaruhi, yakni tujuan intruksional yang ingin dicapai, materi yang diajarkan, guru dan siswa yang harus memainkan peranan serta ada dalam hubungan sosial tertentu, jenis kegiatan yang dilakukan, serta sarana dan prasarana belajar mengajar yang tersedia. ${ }^{2}$ Kelengkapan dari seluruh sistem lingkungan tersebut merupakan penunjang keefektifan suatu proses pembelajaran.

Beberapa syarat pembelajaran dikatakan efektif antara lain, apabila presentasi waktu belajar siswa yang tinggi dicurahkan terhadap kegiatan pembelajaran, rata-rata perilaku melaksanakan tugas yang tinggi di antara siswa, ketetapan antara kandungan materi ajar dengan kemampuan siswa (orientasi keberhasilan belajar) diutamakan, dan mengembangkan suasana belajar yang akrab dan positif. ${ }^{3}$ Selain itu, efektivitas pembelajaran juga dapat dicapai apabila rancangan pada persiapan, implementasi, dan evaluasi dapat dijalankan sesuai prosedur serta sesuai dengan fungsinya masingmasing.

Kesiapan guru dalam penguasaan bidang keilmuan yang menjadi kewenangannya, merupakan modal dasar bagi terlaksananya pembelajaran yang efektif. Guru yang profesional dituntut untuk memiliki persiapan dan penguasaan yang cukup memadai, baik dalam bidang keilmuan maupun dalam merancang program pembelajaran yang disajikan. Selain itu, pelaksanaan pembelajaran menggambarkan dinamika kegiatan belajar siswa yang dipandu dan dibuat dinamis oleh guru. Untuk itu, guru semestinya memiliki pengetahuan, kemampuan, dan keterampilan dalam mengaplikasikan metode dan pendekatan pembelajaran secara tepat. Kompetensi profesional dari guru perlu

\footnotetext{
${ }^{1}$ Anwar Hafid dkk, Konsep Dasar Ilmu Pengetahuan (Cet. 1; Bandung: Alfabeta, 2013), h. 178

${ }^{2}$ Hasibuan dan Moedjiono, Proses Belajar Mengajar (Cet. XII; Bandung: Remaja Rosdakarya, 2008), h. 3

${ }^{3}$ Trianto, Mendesain Model Pembelajaran Inovatif-Progresif (Cet. 2; Jakarta: Kencana Prenada Media Group, 2010), h. 20
} 
dikombinasikan dengan kemampuan dalam memahami dinamika perilaku dan perkembangan yang dijalani oleh para siswa.

Namun sangat disayangkan kenyataan di lapangan belum menunjukkan ke arah pembelajaran yang efektif. Para pendidik masih perlu penyesuaian dengan K13, para guru sendiri belum siap dengan kondisi yang sedemikian plural sehingga untuk mendesain pembelajaran yang efektif masih kesulitan dan berdapak pada hasil belajar. Sistem pembelajaran duduk tenang, mendengarkan informasi dari guru sepertinya sudah membudaya sejak dulu, sehingga untuk mengadakan perubahan ke arah pembelajaran yang aktif, kreatif, dan menyenangkan agak sulit. Padahal dalam implementasi K13 sesuai dengan standar proses pembelajaran, guru dituntut untuk melakukan proses pembelajaran yang memotivasi, interaktif, inspiratif, menyenangkan, menantang, dan memberikan ruang yang cukup bagi prakarsa, kreativitas, dan kemandirian peserta didik sesuai dengan bakat, minat, dan perkembangan fisik serta psikologisnya. ${ }^{4}$

Suasana kelas perlu direncanakan dan dibangun sedemikian rupa sehingga murid mendapatkan kesempatan untuk berinteraksi satu sama lain. Dalam interaksi ini, murid akan membentuk komunitas yang memungkinkan mereka mencintai proses belajar dan mencintai satu sama lain. Proses pembelajaran melibatkan berbagai macam aktivitas yang harus dilakukan, terutama jika menginginkan hasil yang optimal. Salah satu cara yang dapat dipakai agar mendapatkan hasil yang optimal seperti yang diinginkan adalah memberi tekanan dalam proses pembelajaran. Hal ini dapat dilaksanakan dengan memilih salah satu model pembelajaran yang tepat karena pemilihan model pembelajaran yang tepat pada hakikatnya merupakan salah satu upaya dalam mengoptimalkan hasil belajar murid.

Salah satu model pembelajaran yang memungkinkan murid untuk berinteraksi satu sama lain adalah model pembelajaran kooperatif. Model pembelajaran kooperatif adalah pembelajaran dimana siswa bekerja sama dalam kelompok kecil dan saling membantu dalam belajar. ${ }^{5}$ Selain itu kooperatif selaras dengan K13 yang dapat memotivasi murid, memanfaatkan seluruh energi sosial murid, saling mengambil tanggung jawab. Model pembelajaran kooperatif membantu murid belajar mulai dari keterampilan dasar sampai pemecahan masalah yang kompleks. Ironisnya, model pembelajaran kooperatif belum banyak diterapkan dalam pendidikan walaupun orang Indonesia sangat membanggakan sifat gotong-royong dalam kehidupan bermasyarakat.

Model Pembelajaran kooperatif memiliki beberapa tipe. Salah satu tipe model pembelajaran kooperatif yang dapat membangun kepercayaan diri murid dan mendorong partisipasi murid dalam kelas adalah model pembelajaran kooperatif tipe Word Square. Model pembelajaran kooperatif tipe Word Square cocok digunakan di SD/MI kerena kondisi murid yang masih anak-anak membuat murid menyukai hal-hal yang baru dan menarik.

\subsection{Permasalahan}

a. Bagaimanakah Penerapan Model Pembelajaran Kooperatif Tipe Word Square Pada bidang studi Tematik Murid Kelas IV Di SD Muhammadiyah IDI Tello Baru Makassar ?

b. Apakah Model Pembelajaran Kooperatif Tipe Word Square dapat Meningkatkan Hasil Belajar Tematik Murid Kelas IV di SD Muhammadiyah IDI Tello Baru Makassar?

\section{Tinjauan Pustaka}

\subsection{Landasan Teori}

Belajar adalah suatu proses psikologis yang berlangsung dalam interasksi aktif subjek dengan lingkungan, dan menghasilkan perubahan-perubahan dalam pengetahuan, keterampilan, dan sikap yang bersikap konstan/menetap. ${ }^{6}$. Aktifitas tidak dimaksudkan terbatas pada aktivitas fisik, akan

\footnotetext{
${ }^{4}$ Mulyasa, Implementasi Kurikulum Tingkat Satuan Pendidikan kemandirian Guru dan Kepala Sekolah (Cet. 2; Jakarta: Bumi Aksara, 2009), h. 78

${ }^{5}$ Miftahul Huda. Cooperatif Learning Metode, Teknik, Struktur dan Model Penerapan (Cet. IV; Yogyakarta: Pustaka Pelajar: 2013), h. 32.

${ }^{6}$ Abdul Haling. Belajar dan Pembelajaran, (Cet. II; Makassar: Badan Penerbit UNM, 2007), h. 2.
} 
tetapi meliputi aktivitas yang bersifat psikis atau aktivitas mental. Jadi belajar merupakan hal yang pokok. Belajar juga merupakan salah satu faktor yang mempengaruhi dan berperan penting dalam pembentukan pribadi dan prilaku individu ${ }^{7}$, jadi belajar adalah suatu proses yang ditandai dengan adanya perubahan pada diri seseorang. ${ }^{8}$

Perubahan perilaku yang terjadi adalah usaha sadar dan disengaja dari murid yang bersangkutan. Begitu juga dengan hasilnya, murid yang bersangkutan menyadari bahwa dalam dirinya telah terjadi perubahan. Seperti pengetahuannya semakin bertambah atau keterammpilannya semakin meningkat, jika dibandingkan sebelum ia mengikuti proses belajar.

Untuk dapat disebut belajar, maka perubahan harus merupakan akhir dari pada periode yang cukup panjang. Berapa lama waktu itu berlangsung sulit ditentukan dengan pasti, mungkin berlangsung berhari-hari, berminggu-minggu, berbulan-bulan, atau bertahun-tahun. Belajar juga diungkap oleh para ahli adalah sebagai berikut:

"Gagne menganalogkan dalam Abdul Majid, bahwa belajar dengan proses membangun gedung. Anak-anak secara terus menerus membangun makna baru (pengetahuan, sikap, dan keterampilan) berdasarkan apa yang telah mereka kuasai sebelumnya". 9

Dari berbagai definisi diatas, dapat disimpulkan bahwa belajar merupakan perubahan tingkah laku, dengan serangkaian kegiatan. Misalnya, dengan membaca, mengamati, mendengarkan, meniru, dan sebagainya. Selain itu belajar akan lebih baik jika jika subjek belajar mengalami atau melakukannya.

Pembelajaran kooperatif lebih dari sekedar belajar kelompok, karena pembelajaran ini harus ada struktur dorongan dan tugas yang bersifat kooperatif sehingga memungkinkan terjadinya interaksi secara terbuka dan hubungan-hubungan yang bersifat interdependensi yang efektif diantara anggota kelompok. Pembelajaran kooperatif juga mencerminkan keadaan masyarakat luas dan menjadi laboratorium untuk belajar kehidupa nyata. Pembelajaran kooperatif dirancang untuk memanfaat fenomena kerjasama dalam pembelajaran yang menekankan terbentuknya sikap dan perilaku yang demokratis serta tumbuhnya produktivitas kegiatan belajar siswa. Salah satu model pembelajaran kooperatif yaitu tipe Word Square.

Sedangkan model pembelajaran tipe Word Square adalah suatu model pembelajaran yang mengajak siswa mencari jawaban terhadap suatu pertanyaan atau pasangan dari suatu konsep secara kreatif dengan cara mengarsir huruf-huruf dalam kotak sesuai jawaban. Mirip seperti mengisi Tekateki silang tetapi bedanya jawabannya sudah ada namun disamarkan dengan menambahkan kotak tambahan dengan sembarang huruf/angka penyamar atau pengecoh ${ }^{1}$. Model pembelajaran ini sesuai untuk semua mata pelajaran. Tinggal bagaimana guru dapat memprogram sejumlah pertanyaan terpilih yang dapat merangsang murid untuk berpikir efektif. Tujuan huruf/angka pengecoh bukan untuk mempersulit siswa namun untuk melatih sikap teliti dan kritis.

Word Square merupakan salah satu dari sekian banyak metode pembelajaran yang dapat dipergunakan guru dalam mencapai tujuan pembelajaran. Metode ini merupakan kegiatan belajar mengajar dengan cara guru membagikan lembar kegiatan atau lembar kerja sebagai alat untuk mengukur tingkat pemahaman siswa terhadap materi pelajaran yang telah diajarkan. Instrument utama metode ini adalah lembar kegiatan atau kerja berupa pertanyaanatau kalimat yang perlu dicari jawabannya pada susunan huruf acak pada kolom yang telah disediakan.

a. Langkah-langka Model Pembelajaran Word Square

1) Guru menyampaikan materi sesuai kompetensi yang ingin dicapai.

${ }^{7}$ Heri Gunawan. Kurikulum Dan Pembelajaran Pendidikan Agama Islam, (Cet. 1; Bandung: Alfabeta, 2012), h. 104-105

${ }^{8}$ Ahmad Sabri. Strategi Belajar Mengaja Micro Teaching. (Cet. II; Ciputat: Quatum teaching, 2007), h. 31.

${ }^{9}$ Abdul Majid. Belajar dan Pembelajaran Pendidikan Agama Islam (Cet I; Bandung: Rosdakarya,2012), h. 107.

${ }^{1}$ http://blog.tp.ac.id/model-pembelajaran-kooperatif\#ixzz2JU50961WC. Diakses tgl 31 januari 2013. 
2) Guru membuat soal-soal tematik dalam bentuk Word Square.

3) Guru memberikan lembaran kegiatan sesuai contoh kepada setiap murid/setiap kelompok.

4) Guru melakukan tanya jawab mengenai tugas yang telah diberikan.

5) Evaluasi

6) Penutup. ${ }^{1}$

\section{Contoh Soal Word Square}

Arsirlah atau berilah warna huruf-huruf pada kolom sehingga merupakan kata kunci (jawaban) dari pertanyaan.

1. Untuk menjaga kelestarian bahasa daerah maka di sekolah-sekolah diberikan pelajaran bahasa ..

2. Pakaian yang digunakan oleh masyarakat tertentu untuk upacara -upacara adat ataupun upacara pernikahan disebut pakaian ...

$\begin{array}{ccccccc}\text { S } & \text { G } & \text { E } & \text { B } & \text { T } & \text { A } & \text { P } \\ \text { P } & \text { A } & \text { D } & \text { A } & \text { T } & \text { W } & \text { U } \\ \text { A } & \text { C } & \text { A } & \text { M } & \text { P } & \text { A } & \text { K } \\ \text { D } & \text { S } & \text { E } & \text { D } & \text { E } & \text { S } & \text { A } \\ \text { A } & \text { A } & \text { R } & \text { R } & \text { K } & \text { I } & \text { L } \\ \text { N } & \text { P } & \text { A } & \text { U } & \text { U } & \text { L } & \text { N } \\ \text { G } & \text { A } & \text { H } & \text { H } & \text { L } & \text { I } & \text { G } \\ \text { D } & \text { D } & \text { F } & \text { I } & \text { I } & \text { S } & \text { I }\end{array}$

a. Kelebihan Model Pembelajaran Word Square:

1) Melatih kecepatan berpikir murid.

2) Menumbuhkan motivasi belajar murid dalam diri murid.

3) Suasana belajar mengajar di dalam kelas lebih hidup dan lebih menyenangkan,

b. Kelemahan Model Pemebelajaran Word Square:

1. Tugas yang diberikan begitu mudah kerena tinggal diarsir jawabannya sehingga peserta didik bisa saja menebak secara kebetulan.

2. Sebagian murid akan berbuat curang dengan menyontek jawaban temannya saja tanpa perlu berusaha berpikir sendiri.

\section{Pembahasan}

\subsection{Sikap Siswa dalam Kegiatan Pembelajaran}

Aktivitas belajar siswa hasil observasi, siklus I, siklus II dan siklus III yang dilaksanakan oleh peneliti dalam 6 kali pertemuan dengan mengamati beberapa aspek aktivitas belajar siswa. Data observasi ini adalah data kuantitatif dengan jumlah siswa 20 orang pada kelas IV di SD Muhammadiyah IDI Tello Baru Makassar. Dengan hasil pengamatan Pada pertemuan I, murid yang hadir pada saat pembelajaran berlangsung sebanyak 20 murid, murid yang menyimak penjelasan guru(Peneliti) dengan sungguh-sungguh sebanyak 10 murid, murid yang mengajukan pertanyaan

\footnotetext{
${ }^{1}$ Tukiran Taniredja dkk. op .cit., h. 115.
} 
atau tanggapan sebanyak 8 orang, murid yang menunjukkan kekompakan dalam kelompoknya 7 murid, murid yang menunjukkan peran aktif sebanyak 3 murid, murid yang menghargai pendapat teman 9 murid, murid yang bertanggung jawab dengan tugas yang diberikan guru sebanyak 20 murid murid yang memahami soal Word Square sebanyak 7 murid, murida yang kesulitan mengerjakan soal Word Square sebanyak 9 murid dan murid yang antusias dalam mengerjakan soal Word Square adalah 10 murid.. Sedangakan pada pertemuan II, murid yang hadir pada saat pembelajaran berlangsung sebanyak 20 murid, murid yang menyimak penjelasan guru(Peneliti) dengan sungguhsungguh sebanyak 12 murid, murid yang mengajukan pertanyaan atau tanggapan sebanyak 4 orang, murid yang menunjukkan kekompakan dalam kelompoknya 8 murid, murid yang menunjukkan peran aktif sebanyak 5 murid, murid yang menghargai pendapat teman 13 murid, murid yang bertanggung jawab dengan tugas yang diberikan guru sebanyak 20 murid murid yang memahami soal Word Square sebanyak 9 murid, murid yang kesulitan mengerjakan soal Word Square sebanyak 9 murid dan murid yang antusias dalam mengerjakan soal Word Square adalah 12 murid.

Frekuensi kehadiran siswa tergolong tinggi, karena semua murid hadir selama pelaksanaan proses pembelajaran pada siklus I ini. Akan tetapi masih ada sekitar 10-12 murid yang melakukan kegiatan lain pada saat proses pembelajaran.

2.) Siklus II

Sama halnya dengan pengamatan pada siklus I, pada siklus II juga menunjukkan beberapa perubahan yang terjadi pada murid, malah ada beberapa peningkatan dibanding pada siklus I. Dari pertemuan pertama berlangsung hingga berakhirnya siklus II tercatat sejumlah perubahan yang terjadi pada siswa.

Berdasarkan hasil observasi pada pertemuan III, murid yang hadir pada saat pembelajaran berlangsung sebanyak 20 murid, murid yang menyimak penjelasan guru(Peneliti) dengan sungguhsungguh sebanyak 12 murid, murid yang mengajukan pertanyaan atau tanggapan sebanyak 15 murid, murid yang menunjukkan kekompakan dalam kelompoknya8 murid, murid yang menunjukkan peran aktif sebanyak 4 murid, murid yang menghargai pendapat teman 10 murid, murid yang bertanggung jawab dengan tugas yang diberikan guru sebanyak 20 murid murid yang memahami soal Word Square sebanyak 9 murid, murida yang kesulitan mengerjakan soal Word Square sebanyak 9 murid dan murid yang antusias dalam mengerjakan soal Word Square adalah 13 murid.. Sedangakan pada pertemuan IV, murid yang hadir pada saat pembelajaran berlangsung sebanyak 20 murid, murid yang menyimak penjelasan guru(Peneliti) dengan sungguh-sungguh sebanyak 15 murid, murid yang mengajukan pertanyaan atau tanggapan sebanyak 9 murid, yang menunjukkan kekompakan dalam kelompoknya 8 murid, murid yang menunjukkan peran aktif sebanyak 7 murid, murid yang menghargai pendapat teman 13 murid, murid yang bertanggung jawab dengan tugas yang diberikan guru sebanyak 20 murid murid yang memahami soal Word Square sebanyak 9 murid, murid yang kesulitan mengerjakan soal Word Square sebanyak 9 murid dan murid yang antusias dalam mengerjakan soal Word Square adalah 15 murid.

Pada pertemuan V, murid yang hadir pada saat pembelajaran berlangsung sebanyak 20 murid, murid yang menyimak penjelasan guru(Peneliti) dengan sungguh-sungguh sebanyak 15 murid, murid yang mengajukan pertanyaan atau tanggapan sebanyak 9 murid, murid yang menunjukkan kekompakan dalam kelompoknya 9 murid, murid yang menunjukkan peran aktif sebanyak 8 murid, murid yang menghargai pendapat teman 12 murid, murid yang bertanggung jawab dengan tugas yang diberikan guru sebanyak 20 murid murid yang memahami soal Word Square sebanyak 9 murid, murida yang kesulitan mengerjakan soal Word Square sebanyak 6 murid dan murid yang antusias dalam mengerjakan soal Word Square adalah 16 murid.. Sedangakan pada pertemuan VI, murid yang hadir pada saat pembelajaran berlangsung sebanyak 20 murid, murid yang menyimak penjelasan guru(Peneliti) dengan sungguh-sungguh sebanyak 18 murid, murid yang mengajukan pertanyaan atau tanggapan sebanyak 10 murid, yang menunjukkan kekompakan dalam kelompoknya 14 murid, murid yang menunjukkan peran aktif sebanyak11 murid, murid yang menghargai pendapat teman 14 murid, murid yang bertanggung jawab dengan tugas yang diberikan guru sebanyak 20 murid murid yang memahami soal Word Square sebanyak 13 murid, murid yang kesulitan mengerjakan soal Word Square sebanyak 4 murid dan murid yang antusias dalam mengerjakan soal Word Square adalah 17 murid. 


\subsubsection{Refleksi}

Pada Siklus I dibagi dalam 5 kelompok dimana tiap kelompok beranggotakan 4 murid dari 20 murid. Pembagian anggota kelompok dipilih secara acak. Pada awalnya sebagian cenderung tidak puas dengan pembagian kelompok tersebut karena mereka menginginkan teman kelompoknya yang sudah akrab dengan teman mereka, tetapi ada juga dari mereka kelompoknya yang sudah akrab dengan mereka, tetapi ada juga dari mereka yang merasa senang dalam pembagian kelompok karena saling membantu apabila mereka menemukan kesulitan pada saat mengerjakan soal tanpa harus bertanya pada guru.

Pada pertemuan pertama pelaksanaan Siklus I pada tanggal 26 Juli 2019 , sebagai tugas kelompok murid diminta untuk membahas lembar kegiatan siswa (Tes) yang telah disediakan. Pada umumnya, antusias dan keaktifan murid dalam proses belajar mengajar dalam menjawab pertanyaan guru tentang materi yang dibahas serta mengerjakan soal/tugas dapat dikatakan tidak ada. Hal tersebut hanya dilakukan oleh murid yang tergolong pintar serta mencatat saja tiap materi yang diajarkan.

Pembelajaran pada Siklus I secara umum murid belum mampu mengerjakan soal yang berkaitan dengan materi yang diajarkan dengan menggunakan model Word Square dan belum mampu mengkonstruksi sendiri pengetahuannya. Hal ini disebabkan karena model pembelajaran yang diterapkan oleh guru benar-benar masih baru diterapkan di sekolah tersebut sehingga murid masih kurang mengerti cara pelaksanaannya.

Siklus II atau pada pertemuan berikutnya, antusias antara sesama anggota kelompoknya dalam proses belajar mengajar sudah mulai mengalami peningkatan.

Siklus II antusias murid semakin memperlihatkan kemajuan. Hal ini ditandai dengan jumlah murid yang menjawab pertanyaan guru, bertanya tentang materi, dan mengajukan diri untuk mengerjakan soal yang diberikan tanpa diminta langsung oleh guru, dan ketepatan dalam menjawab soal yang diberikan juga mengalami peningkatan.

Pada siklus ke III antusias murid jauh lebih meningkat hal ini dapat di liat dari kerjasama antara anggota kelompok meningkat, dilihat seperti murid yang ditunjuk dapat mewakili kembali kelompoknya mengerjakan soal di papan tulis, dapat mengerjakan soal dengan cepat dan benar, serta tutor yang ditunjuk juga antusias membimbing teman sekelompoknya.

Secara umum dikatakan bahwa seluruh kegiatan pada Siklus III mengalami peningkatan bila dibandingkan dengan Siklus I dan II . Hasil analisis kualitatif terlihat bahwa pada dasarnya penerapan model pembelajaran kooperatif tipe World Square, murid sudah tidak merasa malu untuk meminta bimbingan kepada guru. Pada Siklus I selama kegiatan proses belajar mengajar berlangsung terlihat pada murid sudah mulai termotivasi untuk mengikuti pelajaran tematik disebabkan adanya kerja kelompok dan konteks yang dibicarakan tidak jauh dari apa yang mereka ketahui. Hal ini disebabkan karena model dan pendekatan ini baru diterapkan dalam proses pembelajaran tematik pada murid kelas IV SD Muhammadiyah IDI Tello Baru Makassar. Di samping itu, model pembelajaran yang diterapkan melibatkan murid secara aktif dan tidak membosankan. Setelah diadakan tes Siklus I terlihat adanya peningkatan hasil belajar tematik serta antusias belajar yang mana skor rata-rata yang dicapai murid berada pada kategori rendah.

Setelah dilaksanakan refleksi kegiatan pada Siklus I, maka dilakukan beberapa perbaikan kegiatan yang dianggap perlu demi peningkatan hasil belajar murid pada Siklus II begitupun pada siklus ke III. Pada Siklus I terlihat bahwa antusias murid untuk belajar mengalami peningkatan, di mana murid yang sebelumnya mengharapkan bimbingan guru, murid tersebut telah mampu berusaha sendiri untuk memecahkan masalahnya.

Selain itu, dapat dilihat dari jumlah kehadiran murid, sudah mulai aktif bertanya dan menjawab pertanyaan guru demi keberhasilan kelompoknya. Juga murid merasa senang dan nyaman ketika mereka diberi kesempatan untuk mengemukakan masalah-masalah kontekstual yang berhubungan dengan materi pelajaran. Murid yang mampu mengkonstruksi sendiri pengetahuannya sudah mengalami kemajuan. Hal ini disebabkan karena komunikasi antara murid sudah ada atau telah 
terjalin dengan baik. Setelah diberikan tes Siklus III, rata-rata yang dicapai sudah berada dalam kategori tinggi jika dibandingkan pad Siklus I dan siklus II, maka dapat disimpulkan bahwa penerapan model pembelajaran kooperatif tipe Word Square dapat meningkatkan hasil belajar IPS murid kelas IV SD Muhammadiyah IDI Tello Baru Makassar.

\subsubsection{Pembahasan}

Menurut kriteria ketuntasan minimal (KKM) berdasarkan kompetensi dasar SD Muhammadiyah IDI Tello Baru Makassar yaitu 66, hasil tes pada siklus I menunjukkan bahwa ketntasan hasil belajar tematik murid berkisar 30\%\%, maka dikatakan bahwa keberhasilan siswa terhadap pembelajaran dengan model pembelajaran kooperatif tipe Word Square pada siklus I belum tercapai karena jumlah siswa yang mencapai KKM masih dibawah $85 \%$ dari jumlah keseluruhan siswa. Sedangkan pada siklus II, tes hasil belajar tematik melalui model pembelajaran kooperatif tipe Word Square mencapai persentase 40\%. Dengan persentase tesebut pada siklus II ketuntasan belajar tematik melalui model pembelajaran kooperatif tipe Word Square meningkat namun belum mencapai KKM dan Masih di bawah 85\%. Sehingga di perlukan siklus ke III pada siklus ke III telah di peroleh ketuntasan hasil belajar $85 \%$ dapat disimpulkan bahwa pada siklus III terjadi peningkatan hasil belajar tematik murid yang ditandai oleh ketuntasan belajar meningkat dari $40 \%$ menjadi $85 \%$ sehingga peningkatan ketuntasan belajar mencapai $45 \%$. Hal itu dapat terlihat pada tabel berikut.

Pembelajaran kooperatif tipe Word Square dapat meningkatkan hasil belajar tematik murid karena dalam pembelajaran ini murid dapat saling memberikan pengetahuan dengan menjawab maupun menanggapi pertanyaan yang sebelumnya diajukan oleh rekan sesama siswa sehingga dengan kegiatan tersebut siswa dapat mengungkapkan pendapat atau gagasan-gagasan yang mereka miliki. Hal ini sangat membantu siswa untuk memahami materi yang sedang dipelajari dan dapat mengingatnya dalam waktu yang lama daripada mereka hanya mendengarkan dan menghafalkan materi yang dipelajari. Dalam pembelajaran ini siswa yang dituntut untuk lebih aktif dimana guru hanya berperan sebagai fasilitator.

Pada siklus I, proses pembelajaran dengan model pembelajaran kooperatif tipe Word Square ditandai dengan kegiatan tanya jawab antar murid dengan murid maupun kelompok dengan kelompok yang digunakan untuk mengekplorasi pengetahuan siswa, kemudian dilanjutkan dengan mengerjakan soal-soal mengenai materi yang telah dipelajari. Setelah melakukan refleksi untuk perbaikan pada siklus II dan III, selanjutnya hasil belajar tematik semakin meningkat.

Peningkatan tersebut disebabkan karena dalam pelaksanaan pembelajaran pada siklus III dilakukan perbaikan-perbaikan itu berupa (1) guru dalam memfasilitasi siswa pada kegiatan tanya jawab ataupun meluruskan jawaban mengurangi tempo agar siswa dapat lebih memahami materi yang dipelajari (2) memberikan bimbingan secara satu persatu terhadap siswa yang kurang mampu agar mereka lebih aktif dan bersemangat dalam mengerjakan proses pembelajaran.

\section{Penutup}

\subsection{Kesimpulan}

Berdasarkan hasil pembahasan penerapan model Word Square di kelas IV-A SD Muhammadiyah IDI Tello Baru Makassar, maka ddapat disimpulkan sebagai berikut:

a. Penerapan Model Pembelajaran Kooperatif Tipe Word Square Pada bidang studi Tematik Murid Kelas IV Di SD Muhammadiyah IDI Tello Baru Makassar terlaksana dengan baik dan membantu peserta didik aktif dalam pembelajaran. Penerapan model Word Square meningkatkan keaktifan belajar peserta didik dan dapat membantu untuk melakukan kerjasama dan saling membantu dalam setiap sesi pembelajaran.

b. Penerapan model Pembelajaran Kooperatif Tipe Word Square telah meningkatkan Hasil Belajar Tematik Murid Kelas IV-A di SD Muhammadiyah IDI Tello Baru Makassar. Peningkatan hasil belajar dilihat dari hasil belajar dengan mengerjakan Word Square yang diberikan kepada peserta didik. 


\subsection{Saran}

Penelitian tindakan kelas yang telah diterapkan sebagai usaha untuk melihat peningkatan hasil belajar peserta didik memberikan gambaran bahwa model pembelajaran atau metode pembelajaran dapat digunakan oleh guru dalam waktu kapan saja dan dapat memberikan motivasi kepada guru lain untuk menerapkan metode tersebut di kelas mereka masing-masing, dengan tujuan agar dapat meningkatkan hasil belajar peserta didik. 


\section{DAFTAR PUSTAKA}

Abdurrahman. Mulyono. Pendidikan Anak Berkesulitan Belajar. Jakarta: Renika Cipta, 2003.

Arikunto. Suharsimi. Prosedur Penelitian Penelitian Suatu Pendekatan Praktik. Jakarta: Renika Cipta, 2006.

B. Uno. Hamzah. Teori Motivasi \& Pengukurannya. Jakarta: Bumi Aksara, 2007.

Elfanany. Burhan. Penelitian Tindakan Kelas. Yogyakarta: Araska, 2013.

http://tulis.uinjkt.ac.id/opac/themes/katalog/detail.jsp?id=107883\&lokasi=lokal, $\quad$ diakses $\quad$ pada tanggal 31 januari 2013.

http://skripsiekawijana.blogspot.com/2011/09/penerapan-model-belajar-word- square.html. di akses tanggal 28 September 2011.

Gunawan Heri. Kurikulum dan Pembelajaran Pendidikan Agama Islam. Bandung: Alfabeta, 2012.

Hamalik Oemar. Pendidikan Guru Berdasarkan Pendekatan Kompetensi. Jakarta: Bumi Aksara. 2006.

Haling Abdul. I: Badan Penerbit UNM. 2007.

Huda Miftahul. Cooperatif Learning. Yogyakarta: Pustaka Pelajar. 2013.

Bunyamin. Psikologi Belajar. Paket 1. Surabaya: LAPIS PGMI, 2009.

Majid Abdul. Belajar dan Pembelajaran Pendidikan Agama Islam. Bandung Rosda Karya, 2012.

Mulyasa. Standar Kompetensi dan Sertifikasi Guru. Bandung: Rosda Karya, 2007

Nurdin. Syarifuddin. Model Pembelajaran yang Memperhatikan Keragaman Individu Siswa dalam Kurikulum Berbasis Kompetensi. Quantum Teaching, 2005.

Prasetyo Bambang. Miftahul Lina. Metode Penelitian Kuantitatif. Jakarta: 2012.

Rusman. Belajsar dan Pembelajaran Berbasis Komputer. Bandung: Alfabeta, 2012. ,Model-model Pembelajaran. Jakarta: Rajawali Pers, 2011.

Sabri Ahmad. Strategi Belajar Mengasjar Micro Teaching 